\title{
An evaluation of farmers' perception, awareness, and adaptation towards climate change: a study from Punjab province Pakistan
}

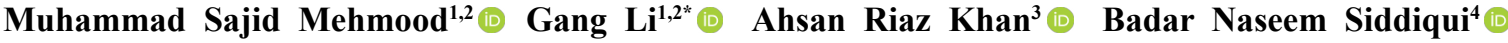

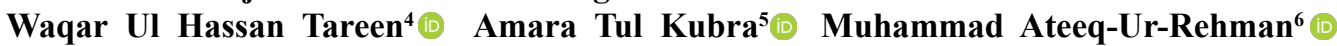

${ }^{1}$ College of Urban and Environmental Sciences, Northwest University, Xi'an 710127, PR China.

${ }^{2}$ Shaanxi Key Laboratory of Earth Surface System and Environmental Carrying Capacity, Northwest University, Xi'an 710127, PR China. E-mail: liglzu@gmail.com. ${ }^{*}$ Corresponding author.

${ }^{3}$ Department of Environmental Sciences, Bahauddin Zakariya University, Multan, Pakistan.

${ }^{4}$ Department of Agricultural Extension, PMAS Arid Agriculture University, Rawalpindi 4600, Pakistan.

${ }^{5}$ Department of Sociology, BZU Bahadur Sub Campus Layyah 31200, Pakistan.

${ }^{6}$ Department of Sociology, PMAS Arid Agriculture University, Rawalpindi 4600, Pakistan.

ABSTRACT: Globally, all environmental sectors are threatened by climate change, most especially to the food and agriculture sectors. Pakistan is a developing country that is most vulnerable to extreme and harsh climatic conditions, especially in Southeast Asia. Climate change has often adverse effects on Pakistan because it is often affected by severe weather conditions. Although, some studies have reported on farmers'perceptiveness regarding climate change adaptation and mitigation, there is still insufficient awareness among Pakistanis 'farmers. Key knowledge is very important for farmers to overcome the harsh climatic conditions for harvesting and saving crops. To bridge this gap, this research discovered the awareness level of climate change, weather conditions, and related factors among Pakistani farmers. Through a stratified random sampling technique, 500 structured questionnaires were distributed among the farmers in four districts of Punjab Pakistan for study analysis. The probit model was used to analyze the farmer's perception regarding climate change, socio-demographic and economic variables. The findings of this research showed that $75 \%$ of farmers are aware of climate change. Perception of climate change between farmers was directly associated with agriculture experience, farmers' age, land ownership status, level of education, information sources, and access to extension. Also, our research showed that farmers'assessment of adaptive behavior showed that farmers are actively implementing crop diversification, irrigation, and other adaptation strategies. Results of this study will help government agencies and policymakers in Pakistan and other regions to develop sustainable adaptation measures in the framework of climate change. Keywords: climate change, awareness, climatic parameters, perception, adaptation strategies, Pakistan.

Uma avaliação da percepção, consciência e adaptação dos agricultores em relação às mudanças climáticas: um estudo da província de Punjab, Paquistão

RESUMO: Globalmente, todos os setores ambientais estão ameaçados pelas mudanças climáticas, principalmente para os setores de alimentos e agricultura. O Paquistão é um país em desenvolvimento mais vulnerável a condições climáticas extremas e adversas, especialmente no sudeste da Ásia. As mudanças climáticas costumam ter efeitos adversos no Paquistão, porque muitas vezes é afetado por condições climáticas severas. Embora alguns estudos relatem a percepção dos agricultores em relação à adaptação e mitigação das mudanças climáticas, ainda há consciência insuficiente entre os agricultores paquistaneses. O conhecimento chave é muito importante para os agricultores superarem as duras condições climáticas para a colheita e economia de safras. Para preencher essa lacuna, esta pesquisa pretende descobrir o nivel de consciência das mudanças e condições climáticas e fatores relacionados entre os agricultores paquistaneses. Por meio de uma técnica de amostragem aleatória estratificada, 500 questionários estruturados foram distribuidos entre os agricultores em quatro distritos de Punjab Paquistão para análise do estudo. Omodelo probit foi usado para analisar a percepção do agricultor em relação às mudanças climáticas, variáveis sócio-demográficas e econômicas. Os resultados desta pesquisa mostram que 75\% dos agricultores estão cientes das mudanças climáticas. A percepção da mudança climática entre os agricultores foi diretamente associada à experiência agrícola, idade dos agricultores, situação de propriedade da terra, nível de educação, fontes de informação e acesso à extensão. Além disso, nossa pesquisa mostrou que a avaliação dos agricultores sobre o comportamento adaptativo mostra que eles estão implementando ativamente a diversificação de culturas, irrigação e outras estratégias de adaptação. Os resultados deste estudo ajudarão agências governamentais e formuladores de políticas no Paquistão e em outras regiões a desenvolver medidas de adaptação sustentáveis no contexto das mudanças climáticas.

Palavras-chave: mudanças climáticas, consciência, parâmetros climáticos, percepção, estratégias de adaptação, Paquistão.

\section{INTRODUCTION}

Worldwide, society is facing an immense amount of environmental challenges (like global warming, climate change, pollution, etc.), but climate change is one of the boundless universal challenges among these (STEFFEN et al., 2015). Climatic changes affect the world, causing widespread upheaval and inevitably affecting the economy (BENISTON \& HAEBERLI, 2000; KOHLER \& 
MASELLI, 2009; HUONG et al., 2019a). There are various aspects (for instance agriculture, ecosystem, water resources, forestry, infrastructure, fisheries, and human health) that are considered essential for livelihoods (BENISTON, 2003; PULHIN et al., 2006). Many ecosystems have been pretentious by climate changes through variations in environment events in the shape of rising temperature, increase in sea level, changing rainfall patterns, glaciers melting and devastation of floods (IPCC, 2007). According to IPCC (2007), in the previous century, the normal temperature has risen by $0.6^{\circ} \mathrm{C}$ and it is estimated that the temperature will rise by $2-3^{\circ} \mathrm{C}$ by the end of this century (IPCC, 2007). Therefore, due to the emission of greenhouse gases, climate change is expected to be greater than in the last century (PACHAURI \& SPRENG, 2011).

In developing countries, poverty prevails where people's livelihood mainly depends upon agriculture their climate change is the main concern (FAHAD et al., 2018; HUONG et al., 2019b). Climatic threats such as cyclones, droughts, warm or cold waves, blizzard rises, and floods get occurred due to climatic variations and increasingly all over the world (FIELD et al., 2012; ZHANG et al., 2013; HUONG et al., 2017). The agricultural sector has faced various risks regarding production, marketing, and finance that are linked to climatic risks (VELANDIA et al., 2009). Poor rural communities are vulnerable to climate hazards because of society's factors such as population growth, low literacy rates, lack of settlement management, and a lack of awareness, that are considered as key factors (HUONG et al., 2019a; HUONG et al., 2019b). Climate change impacts vary from region to region. Farmers are suffering more losses in developing regions because of lack of diversification capabilities, limited infrastructure, low awareness, lack of skills, limited financial capabilities, inability to predict extreme climate events, and low adaptability (KURUKULASURIYA \& MENDELSOHN, 2007).

Pakistan is one of the most vulnerable countries in the world that are extremely susceptible to climate events. The country has a large population, extreme poverty, and is intensely exposed to the adverse effects of natural calamities. In Pakistan, various climatic pressure like droughts, avalanches, cyclones, floods, landslides, and snowstorms are faced by different areas of the country. In the gross domestic product of Pakistan, the agriculture sector is $22 \%$ that is contributing $45 \%$ to the total labor force of Pakistan; therefore, any adverse effects of climatic events may affect millions of people's livelihoods
(GOP, 2013). The agricultural sector and economy of the country severely affected from the past natural disasters (for example, the last three floods in 2010, 2011, and 2014), that have a lot of harm to various areas including forestry, livestock, fisheries, animal sheds, agricultural equipment, tube wells, fertilizers, seed stocks, houses, and infrastructure. Besides this, approximately two hundred and fifty thousand farming families and nearly 1 million acres of land (cultivation area) were affected (NDMA, 2014; FAHAD \& WANG, 2018).

Farmers' awareness level, vulnerability, adaptability, and impacts of climate change on the region have been investigated in various studies. However, this kind of study is worthwhile because Pakistan is very susceptible to climate concerns. According to the region, Climate change and perceptions are different (MANDLENI \& ANIM, 2011). Farmers require climate change awareness to deal with their negative impacts. According to the existing literature (HASSAN \& NHEMACHENA, 2008; IDRISA et al., 2012; MTAMBANENGWE et al., 2012; AJUANG et al., 2016; HUONG et al., 2019b), Farmers' decisions to adaptation strategies of climate change are directly correlated to farmers' climate change awareness and might reduce vulnerability and improve livelihoods.

Surprisingly, research on climate change awareness, directly related to farmers' adaptation strategies, is at the forefront of Pakistan's Punjab province, which has been hit by the most climaterelated circumstances in Pakistan. To bridge the gap in the study, research is helpful to deliver the evidence of farmers' climate change awareness and the contributing factors that might provide targeted measures for public and private organizations. Therefore, this study assessed the awareness of farmers regarding climate change and its key influencing factors.

The following parts of the manuscript are arranged as section 2 contains methodology, results, and discussion written in section 3 while section 4 has conclusions and recommendations

\section{METHODOLOGY}

\section{Sampling design}

Most susceptible districts of Punjab province were carefully chosen for a household survey. Data was collected through a structured questionnaire by using a simple random sampling technique. Face to face interviews was conducted in this survey that meets the socioeconomic factors of a 
farm household in the study area. The questionnaire contained several questions about their climate change awareness, socio-economic, and demographic information. Household farms were convinced that the data will be kept confidential at all stages in the household survey, and according to ethics and moral standards, the information will only be utilized for study objectives. To eliminate the language barriers between the interviewers and farmers, the questionnaires were first written in English and after that interpreted into local languages like Urdu, Saraiki, Punjabi. Before starting household surveys and data collection, the interviewers were properly trained. Under the supervision of the main author, the data of 15 farmers were pre-tested. Final data collection began after removing all the ambiguities from the survey.

\section{Data collection and sampling}

Farm households' data was collected through a random sampling technique, but the vulnerable districts of Punjab province of Pakistan were purposively selected based on their vulnerability frequent climatic events (droughts and floods) between 2010 and 2014. The author's main goal is to target vulnerable populations in selected survey areas in Punjab province. First of all, four regions of Bhakkar, Layyah, Muzaffargarh, and Dera Ghazi Khan were purposely selected) because of their agricultural importance, flood history, and severe flood damage caused by climate change. Secondly, flood-affected tehsils were chosen from each district. Thirdly, various flood-affected areas and small towns were selected casually (table 1). Five hundred farmers were chosen to collect data through a structured questionnaire to make a sample size for the study. 7\% margin error with a confidence level of $95 \%$ used by (FAHAD et al., 2018). Another literature (HUSSAIN $\&$ THAPA, 2012), taken around 7\% margin error.

$$
n=\frac{N}{\left(1+N e^{2}\right)}
$$

$\mathrm{n}=$ sample size, $\mathrm{N}=$ total no of farm households in an area and $\mathrm{e}=$ exactness value, set as $\pm 7 \%(0.07)$.

\section{Socio-economic factors}

According to earlier literature (BAYARD et al., 2007; ODUNIYI, 2013; FAHAD et al., 2018), climate change awareness is determined by several socio-economic factors, including agricultural area and geographical features. Assets such as agricultural areas improve alertness of climate change employing participation in agricultural activities. Similarly, climate change awareness through the delivery of information about innovative technologies, access to information, climate challenges, and climate predictions are positively linked to these factors that considered as institutional determinants (BAYARD et al., 2007; MADDISON, 2007; KABUBOMARIARA, 2008; BRYAN et al., 2009; DERESSA et al., 2009; DERESSA et al., 2011; AYDOGDU \& YENIGÜN, 2016; HUONG et al., 2019a). Awareness of climate crises varies depending on what kind of formal services are given by institutions. Contact to extension services has a positive impact on climate change responsiveness through the knowledge given by extension staff.

Table 1 - Surveyed areas of study.

\begin{tabular}{lcc}
\hline Districts & Tehsils & Villages \\
\hline Bhakkar & Bhakkar & 10 \\
& Darya Khan & 15 \\
\hline Layyah & Kaloorkot & 12 \\
& Layyah & 20 \\
\hline Muzaffargarh & Karor Lal Eason & 15 \\
& Muzaffargarh & 25 \\
\hline Kot Addu & 10 \\
\hline Dera Ghazi Khan & Jatoi & 13 \\
\hline
\end{tabular}




\section{Probit model}

In order to justify the awareness level with different socio-economic determinants of farmers, the probit model was used, which is taken as a binary variable that farmers have to listen to or not about climate change.

$\mathrm{Y}=\alpha_{\mathrm{i}}+\mathrm{X}_{\mathrm{i}} \beta_{\mathrm{i}}+\varepsilon_{\mathrm{i}}$

The level of awareness is the dependent variable (Y) regarding climate change. $\mathrm{Xi}$ is factors that affected the farmers' awareness level of climate change, $\beta \mathrm{i}$ are the coefficients, while $\mathrm{Ei}$ is the standard errors.

\section{RESULTS}

Farmers'awareness about climate change

The farm households were interviewed on their awareness level of the changing climate and extreme weather conditions. The findings revealed that the majority of survey contributors (75\%) were aware of climate change. As shown in table 2, almost $25 \%$ of survey participants have inadequate knowledge of climate change. Our results are consistent with the Pakistan bureau of statistics (GOP, 2013) and most of the regions have a hot climate.

Other undeveloped countries (like Africa) farm households have a higher level of awareness than Pakistan farmers as shown in results, where $86 \%$ of farmers are aware of climate changes regarding temperature (MANDLENI \&ANIM, 2011; HUONG et al., 2017), 75\% of farmers know about climatic variations in Nigeria (SOFOLUWE et al., 2011) while HASAN and AKHTER (2011) pointed out that $85 \%$ of farmers are conscious of climate change in Bangladesh. Compared with different developing countries, the climate change sensitivity of the geography is significantly higher than that of Kenya. In Kenya,52.2\% of farmers are vigilant of climate variations such as precipitation (AJUANG et al., 2016).

\section{Perception of climate change \\ It is important to know about farmers'} views about climate change, for instance, the perception of climatic parameters (like droughts, temperature, floods, cyclones, and rainfall) to design appropriate measures for climate change and other change countermeasures, which are helpful to realize the current and future adaptation behaviors and to make adaptive decisions (ESHAM \& GARFORTH, 2013). Our results showed that respondents have intensely noticed the climatic events as displayed in table 3 .

About temperature, the majority of the respondents perceived high temperature (68\% in Bhakkar District, $77 \%$ in Layyah, $82 \%$ in Muzaffargarh, $90 \%$ in Dera Ghazi Khan). Correspondingly precipitation pattern $(75 \%$ in Bhakkar, Layyah 70\%, Muzaffargarh 78\%, DG Khan 73), the response of high increase in flood was answered by ( $83 \%$ in Bhakkar, $74 \%$ in Layyah, $80 \%$ in Muzaffargarh and DG Khan 37\%). Likewise, drought ( $27 \%, 36 \%, 25 \%$, and $18 \%$ ) and cyclones $(17 \%, 20 \%, 8 \%$, and $5 \%$, respectively) were indicated by the farm household that adversely impacts on agriculture productivity as shown in figure 1 .

Farmers' perceived impact of climate change on productivity

Farmers' perception of the impact of climate change on productivity by the district is shown in table 4 . The findings indicated that $84 \%$ of the surveyed farm households in Bhakkar District, $73 \%$ in Layyah, $72 \%$ in Muzaffargarh, and $89 \%$ in DG Khan District as shown in figure 2. Similarly, about $75 \%$ of Bhakkar farmers, $80 \%$ of Layyah respondents, $78 \%$ of Muzaffargarh, and $60 \%$ of farmers in the DG Khan region have perceived their future predictions that climate change would likely affect their farm productivity. Most of the farmers said that their farm productivity was affected by climatic change. They had knowledgeable experience about climate change's impact on farmhouse productivity.

Previously practiced and potential future adaptation strategies by farm household

Several adaptation measures were practiced on the farm in response to the unexpected

Table 2 - Awareness of farmers regarding climate change.

\begin{tabular}{lcc}
\hline level of awareness & Frequency & Percentage \\
\hline Aware & 375 & $75 \%$ \\
Not aware & 125 & $25 \%$ \\
\hline
\end{tabular}

Source: Field survey.

Ciência Rural, v.52, n.3, 2022. 
Table 3 - Famers' perception regarding climate change in surveyed districts.

\begin{tabular}{|c|c|c|c|c|c|}
\hline \multirow[t]{2}{*}{ Districts } & \multirow[t]{2}{*}{ Climatic parameters } & \multicolumn{4}{|c|}{ 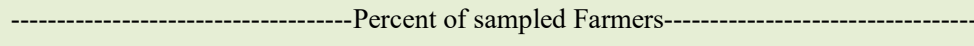 } \\
\hline & & Low increase $(\%)$ & Medium increase $(\%)$ & High increase (\%) & Do not know (\%) \\
\hline \multirow{5}{*}{ Bhakkar } & Temperature & 6 & 8 & 68 & 18 \\
\hline & Precipitation pattern & 3 & 18 & 75 & 4 \\
\hline & Floods & 5 & 7 & 83 & 5 \\
\hline & Droughts & 10 & 55 & 27 & 8 \\
\hline & Cyclones & 47 & 25 & 17 & 11 \\
\hline \multirow{5}{*}{ Layyah } & Temperature & 4 & 14 & 77 & 5 \\
\hline & Precipitation pattern & 8 & 15 & 70 & 7 \\
\hline & Floods & 2 & 16 & 74 & 8 \\
\hline & Droughts & 12 & 48 & 36 & 6 \\
\hline & Cyclones & 32 & 38 & 20 & 10 \\
\hline \multirow{5}{*}{ Muzaffargarh } & Temperature & 7 & 8 & 82 & 3 \\
\hline & Precipitation pattern & 6 & 12 & 78 & 4 \\
\hline & Floods & 9 & 8 & 80 & 3 \\
\hline & Droughts & 20 & 44 & 25 & 11 \\
\hline & Cyclones & 68 & 14 & 8 & 10 \\
\hline \multirow{5}{*}{ Dera Ghazi Khan } & Temperature & 2 & 5 & 90 & 3 \\
\hline & Precipitation pattern & 6 & 9 & 73 & 12 \\
\hline & Floods & 25 & 33 & 37 & 5 \\
\hline & Droughts & 48 & 28 & 18 & 6 \\
\hline & Cyclones & 45 & 12 & 5 & 36 \\
\hline
\end{tabular}

Source: field survey.

climate events, which farmers indicated, and future adaptation measures are shown in table 5. Adaptation measures like irrigation (82\% in Bhakkar, $91 \%$ in Layyah, $82 \%$ in Muzaffargarh, $88 \%$ in DG Khan), crop diversification (74\% in Bhakkar, $80 \%$ in Layyah, $75 \%$ in Muzaffargarh, $67 \%$ in DG Khan), and crop type change (75\% in Bhakkar, $47 \%$ in Layyah, $73 \%$ in Muzaffargarh, $62 \%$ in DG Khan) have been recognized as the most urgent ones in the surveyed area.

Farmers in surveyed areas of Pakistan's Punjab province also used various advanced practices to protect from natural disasters. Most farmers in the research area are also accustomed to storing unused water because they stated that they are already facing a shortage of irrigation water. The survey results revealed that all farmers in the surveyed area depend on cultivation for livelihoods. Pakistan is an agricultural state where most of the farmers with low living standards. Their land holding capacity is also low, and they are mainly engaged in agriculture activities. Farmers have relatively low living standards are primarily susceptible to climate risks such as droughts and floods. Furthermore, it has also been observed that some farmers were using typical adaptation strategies, which might be a lack of knowledge and literacy about progressive adaptation approaches (AHMAD et al., 2013).

Farmers in South Asia have adopted some primary adaptation measures of climate change, those farmers who are making changes in crop patterns, using different crop varieties, short-term planting (KRUPNIK et al., 2015), dates of sowing to prevent damaging floods, rainfall, and high temperatures (JAIN et al., 2015). Moreover, making the cattle farming a diversified and crop mixed method (THORNTON \& HERRERO, 2014).

Results showed that agricultural people are very aware of previous weather changes and recognized that more changes may occur in the future. In addition to increasing resilience, farmers are taking the lead in adapting to farm management adaptation practices that may have been adopted to practice non-climate change with additional farm productivity benefits (STERRETT, 2011). Further efforts are required to better understanding how farmers prioritize and decide to adopt different adaptation measures. This behavioral change may be caused by many factors such as political,

Ciência Rural, v.52, n.3, 2022. 


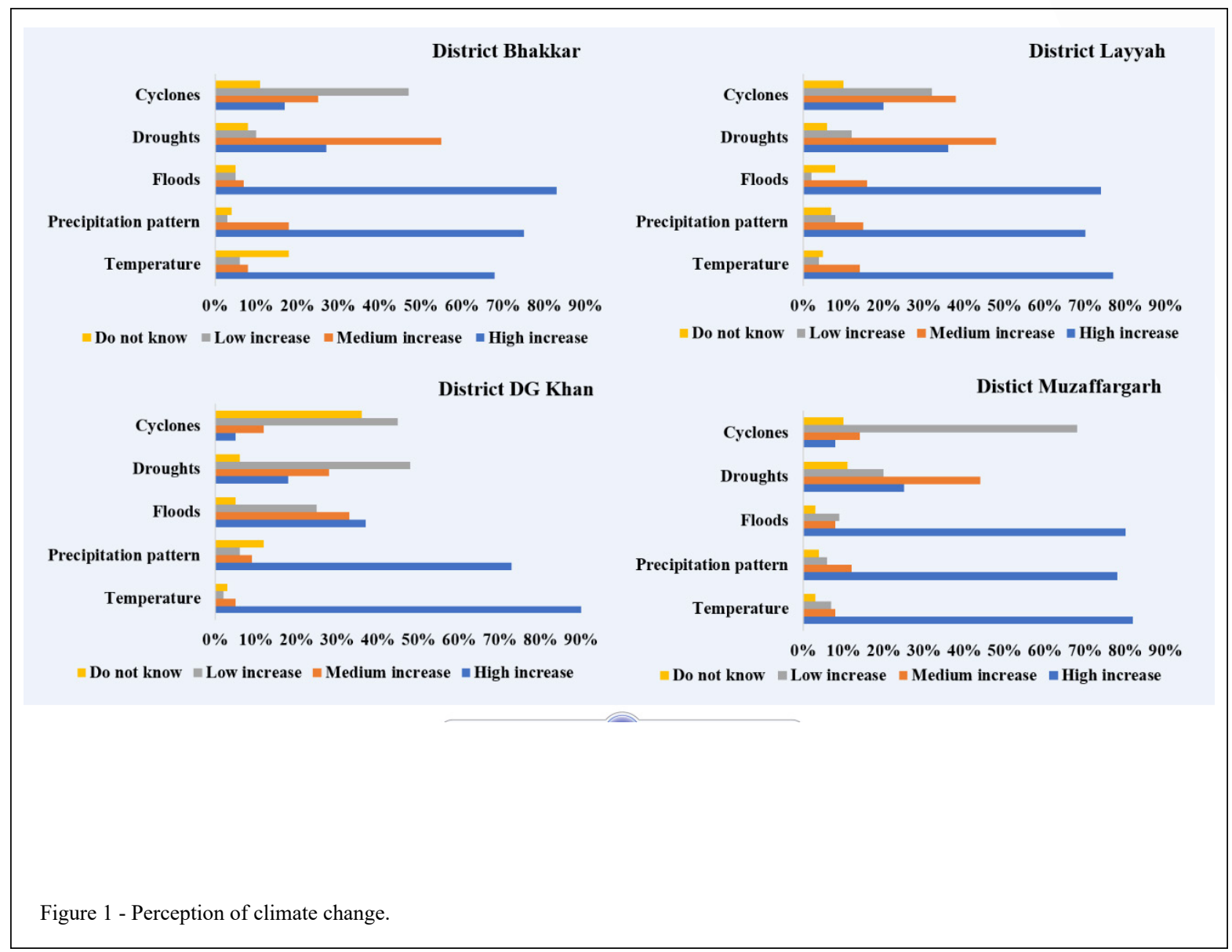

institutional, economic, agronomic, and as well as cultural ones. The results also reported that $28 \%$ of farmers did not take any form of adaptation measures, suggesting, they were still unable to implement or adopt more agricultural patterns. Lack of resources, lack of adequate agricultural information, and associated skills are some potential constraints that were observed by JAIN et al. (2015). DI FALCO et al. (2011) reported that in remote areas, the lack of information may be one of the biggest obstacles in the adoption of climate change adaptation strategies. This situation is particularly applicable to Pakistan, where research on environmental vulnerability and risk perception is still insufficient (HUSSAIN \&

Table 4 - Farmers' perception regarding climate change impact on productivity.

\begin{tabular}{|c|c|c|c|c|c|c|}
\hline \multirow[t]{2}{*}{ District } & \multicolumn{3}{|c|}{--Productivity is already affected by climate change--- } & \multicolumn{3}{|c|}{--productivity will be affected after climate change- } \\
\hline & Yes $(\%)$ & No $(\%)$ & Do not know (\%) & Yes $(\%)$ & No $(\%)$ & Do not know (\%) \\
\hline Bhakkar & 84 & 13 & 3 & 75 & 7 & 18 \\
\hline Layyah & 73 & 21 & 6 & 80 & 16 & 2 \\
\hline Muzaffargarh & 72 & 26 & 4 & 78 & 16 & 4 \\
\hline Dera Ghazi Khan & 89 & 4 & 7 & 60 & 33 & 7 \\
\hline
\end{tabular}

Source: field survey. 


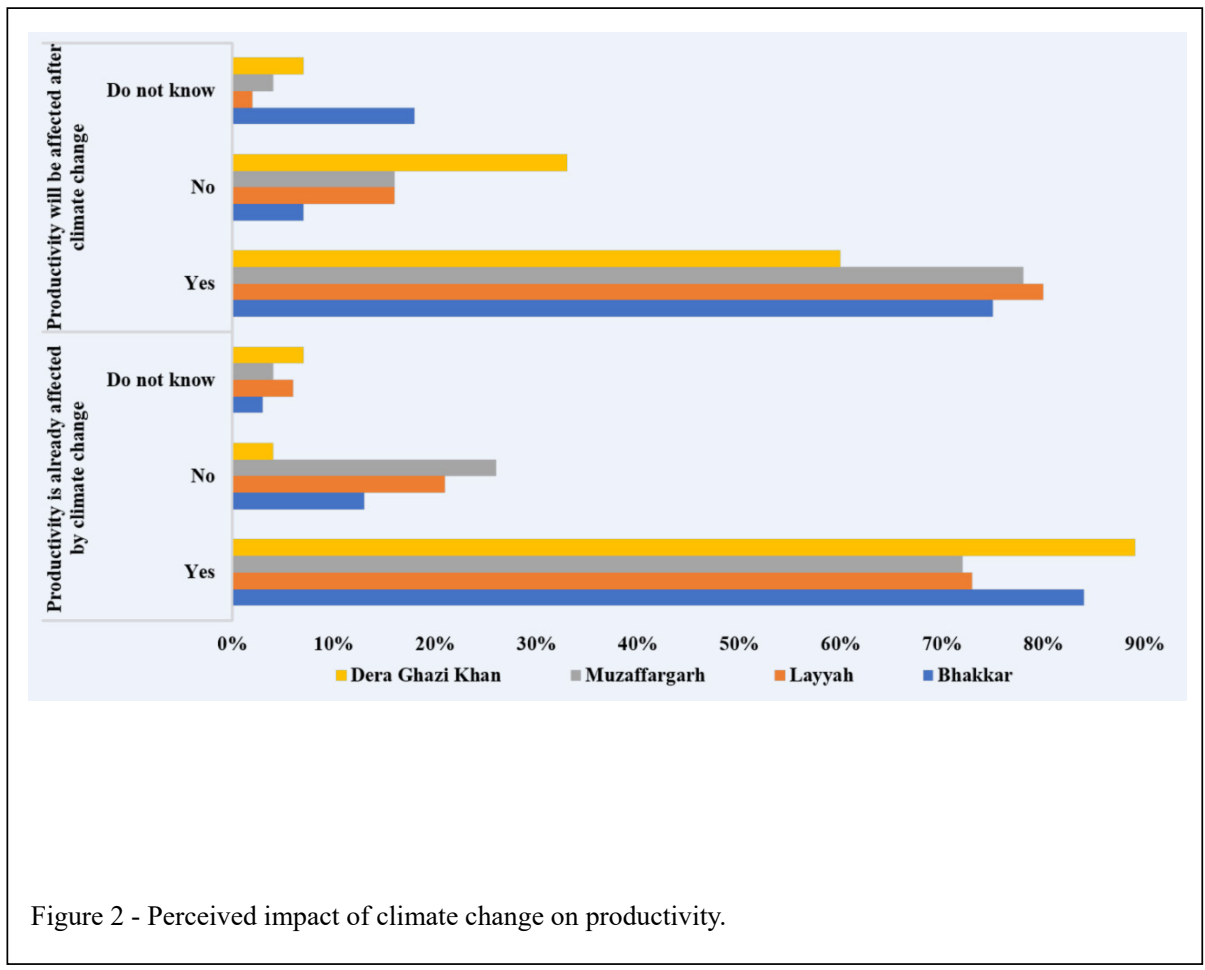

MUDASSER, 2007). ADGER and KELLY (1999) argued that timely adaptation might decrease the adverse climate change effects compared to those who adopt later.

\section{Descriptive analysis}

Descriptive analysis, in which the dependent variable was farmers' climate change awareness level, while the farmer is conscious of

Table 5 - Farm households' earlier practiced and potential upcoming adaptation strategies.

\begin{tabular}{|c|c|c|c|c|c|c|c|c|}
\hline \multirow[b]{2}{*}{ Adaptation Strategies } & \multicolumn{2}{|c|}{---------Bhakkar-------- } & \multicolumn{2}{|c|}{----------Layyah-------- } & \multicolumn{2}{|c|}{-----Muzaffargarh----- } & \multicolumn{2}{|c|}{---Dera Ghazi Khan--- } \\
\hline & $\begin{array}{l}\text { Practices } \\
\text { previously } \\
\text { adopted }\end{array}$ & $\begin{array}{l}\text { Potential } \\
\text { future } \\
\text { practice } \\
\text { options }\end{array}$ & $\begin{array}{l}\text { Practices } \\
\text { previously } \\
\text { adopted }\end{array}$ & $\begin{array}{l}\text { Potential } \\
\text { future } \\
\text { practice } \\
\text { options }\end{array}$ & $\begin{array}{l}\text { Practices } \\
\text { previously } \\
\text { adopted }\end{array}$ & $\begin{array}{l}\text { Potential } \\
\text { future } \\
\text { practice } \\
\text { options }\end{array}$ & $\begin{array}{l}\text { Practices } \\
\text { previously } \\
\text { adopted }\end{array}$ & $\begin{array}{l}\text { Potential } \\
\text { future } \\
\text { practice } \\
\text { options }\end{array}$ \\
\hline Change irrigation & 82 & 18 & 91 & 9 & 82 & 18 & 88 & 12 \\
\hline Change crop type & 75 & 25 & 47 & 53 & 73 & 27 & 62 & 38 \\
\hline Crop diversifications & 74 & 26 & 80 & 20 & 75 & 25 & 67 & 33 \\
\hline $\begin{array}{l}\text { Changes in land use for non-farm } \\
\text { activities }\end{array}$ & 62 & 38 & 40 & 60 & 27 & 73 & 82 & 18 \\
\hline Change in cropping patterns & 50 & 50 & 35 & 65 & 56 & 44 & 15 & 85 \\
\hline Mechanization of farms & 40 & 60 & 42 & 58 & 37 & 63 & 17 & 83 \\
\hline Cultivating short duration crops & 37 & 63 & 19 & 81 & 45 & 55 & 11 & 89 \\
\hline Change crop variety & 32 & 68 & 77 & 23 & 52 & 48 & 80 & 20 \\
\hline Water and soil management & 26 & 74 & 80 & 20 & 25 & 75 & 67 & 33 \\
\hline Change seed quality & 24 & 76 & 26 & 74 & 10 & 90 & 13 & 87 \\
\hline
\end{tabular}

Source: field survey. 
climate change is denoted by zero and does not aware is by one. Ten (10) independent variables were used in this study are shown in table 6. The share of land owned is part of the total agricultural area. Dummy variables are used for non-agricultural incomes. Zero means the farmer's income is non-agricultural income, one means other income sources. Similarly, a dummy variable is used for the acquisition of a credit, where zero represents the credit admittance of the farmer household, for else, it is one. Correspondingly, for variable extension service access, a fake variable is chosen and encode it as zero, which means that the farmer has extension services access, otherwise it is one. Additional access to the info sources is also regarded as a fake variable, where access to the information source was represented by zero, and one for otherwise.

\section{Probit model results}

A multicollinearity test had been performed amongst the descriptive variables, while the value of the variance inflation factor (VIF) was lower than 10. Therefore, the study's finding did not report multicollinearity issues in the descriptive variables. The probit model method is used for factors related to farmers' climate change awareness level.

The results shown in table 7 indicated that between the descriptive determinants, the "age of farm households" was significant (p-value 0.025, coefficient 0.015). For example, with the aging of farmers, farmers are increasingly aware of climate change. It can be said, older farmers have additional information and experience than young farmers. Farm households' education level was very significant (p-value 0.001, coefficient 0.057). That is an indication of a farmer's educational level rises, he or she has more aware of climatic events. The relationship between the family size variable is not significant (p-value is 0.131 , the coefficient is -0.057), indicating that different family members and they are involved in different occupations, the farmers' awareness of climate change will be less aware. Farmers' farming experience is significantly positive with dependent variables (the coefficient 0.413 and p-value 0.000 ). Farmers' knowledge of climate change indicates that experienced farmers have sufficient awareness of climate change than inexperienced farmers. The relationship among variable and agricultural area climate change awareness is not significant ( $p$-value is 0.891 , the coefficient is 0.007 ).

A significant relationship is present between land ownership the climate change awareness at (p-value 0.000 and coefficient 0.601 ), which shows that farmers who had their land having more knowledge than those who are tenants and had rented land. Off-farmhouse income is also significant at $\mathrm{p}$-value 0.015 but has a negative coefficient -0.390 , which showed that farmers who had nonagricultural income having poor awareness about climate change rather than farming. No statistical significance (coefficient 0.109, p-value 0.491) was noted in terms of variable access to credit. The acquisition of extension services showed a positive coefficient (1.122) and the p-value for the dependent variable

Table 6 - Descriptive statistics of the selected variables.

\begin{tabular}{|c|c|c|c|}
\hline Variables & Description & Mean & $\mathrm{SD}$ \\
\hline Dependent variable & Awareness level & & \\
\hline Farmers' level of awareness about climate change & If aware of 0 , otherwise 1 & 0.29 & 0.47 \\
\hline Independent variables & Socioeconomic factors & & \\
\hline Age of respondent & years & 43.65 & 15.21 \\
\hline Education & Schooling years & 6.10 & 4.91 \\
\hline Household size & Numbers & 5.23 & 2.21 \\
\hline Farming experience & Years of farming & 1.89 & 0.65 \\
\hline Cultivated area & Acres & 2.52 & 1.79 \\
\hline Landholding & Acres & 1.83 & 0.67 \\
\hline Off-farm income & If non agriculture income 0 , otherwise 1 & 0.77 & 0.441 \\
\hline Credit accessibility & 0 if accessible, 1 otherwise & 0.53 & 0.510 \\
\hline Extension services access & If Access 0 , otherwise 1 & 0.937 & 0.469 \\
\hline information sources accessibility & If accessible 0 , otherwise 1 & 0.73 & 0.469 \\
\hline
\end{tabular}

Source: Field survey, SD: standard deviation. 
Table 7 - Probit model values of relationship between the farmers' awareness of climate change and socioeconomic characteristics.

\begin{tabular}{lccc}
\hline Independent Variables & Coefficients & Standard error & p-values \\
\hline Farmers' Age & 0.015 & 0.007 & $0.025^{* *}$ \\
Education level & 0.057 & 0.019 & $0.001^{* * *}$ \\
Size of Family & -0.057 & 0.039 & 0.131 \\
Agricultural Experience & 0.413 & 0.211 & $0.000^{* * *}$ \\
Agricultural land & 0.007 & 0.053 & 0.891 \\
Land holdings & 0.601 & 0.133 & $0.000^{* * *}$ \\
Off-farm house income & -0.390 & 0.166 & $0.015^{* *}$ \\
Credit access & 0.109 & 0.156 & 0.491 \\
Extension services access & 1.122 & 0.393 & $0.001^{* * *}$ \\
information sources access & 0.557 & 0.196 & $0.003^{* * *}$ \\
\hline
\end{tabular}

Note: ${ }^{*}, * *$ and ${ }^{* * *}$ are significant at level of $10 \%, 5 \%$ and $1 \%$ respectively. Source: Field survey.

is 0.001 , which is significantly correlated. This indicated that farmers with better access to extension services have a better awareness of climate change. The variable for accessibility of information is statistically significant (p-value is 0.003 , the coefficient is 0.557 ), which means that farmers with proper sources of information are more aware of climate change. It means that the more information sources or knowledge about climate changes are obtained, the stronger the awareness of farmers.

\section{DISCUSSION}

The most significant correlation with climate change awareness and age is highly considered among all socio-economic variables. Farmer awareness grows with age. This shows younger farmers are less aware of climate change than that of older once. Prior research (BAYARD et al., 2007; OLAJIDE et al., 2011) supported our results, who specified that older farmers are sufficiently aware of climate change than young farmers.

Education is an essential factor for spreading the awareness of climate change, and our research displayed that variable education is positively connected to farmers' awareness. For example, if farmers receive education for another year, they will become more aware of climate change. Our results are coherent with (MADDISON, 2007; DERESSA et al., 2009; DERESSA et al., 2011), who described that with the improvement of farmers' education may increase the possible chance of climate change adaptation. Conversely,, our results are inconsistent with (BAYARD et al., 2007; KABUBO-MARIARA, 2008) who disclosed the opposite correlation between education and climate change-related awareness.

We have reported that the variable of farming experience strongly influences the awareness of climate change. Like, farmers' climate change awareness increases with growing farming experience. Our research results supported the research of MADDISON (2007), who founded that farmers with more agricultural experience are more informative. However, our research results are opposing the research of OKONYA et al. (2013), who examined the negative correlation among farmer's climate change awareness and experience.

The family size variable specifies that a larger family size reduces farmers' climate change perception. The results are the opposite of ACQUAH (2011), who founded that the farmers' family size is positively correlated with farmers' concept of climate change.

Association between the farming area and the awareness of farmers about climate change is not significant. For example, as the farming area increases, farmers are less expected to be familiar with climate change. In other words, farmers with a large cultivated area are less aware than farmers with a less cultivated area. Our results differ from ODUNIYI (2013).

The research results showed that the status of land ownership is a positive correlation with climate change awareness. For example, farmers who had their landholding are more aware of climate change than farmers who have renter status or lease land. Our results are similar to the earlier study of ODUNIYI (2013), who defined that landowners as a greater extent of climate change awareness than a farmer with tenant status or leased land.

Ciência Rural, v.52, n.3, 2022. 
The off-farm wage is negatively correlated with climate change awareness. For example, if members of a farmer's family engaged in occupations other than agriculture, the lower is the farmers' understanding of climate change. Results are very consistent with (HUONG et al., 2019a; HUONG et al., 2019b), who stated that the correlation between off-farm earning and climate change awareness is not significant.

Access to the credit of our research findings support the research findings of MUDOMBI et al. (2014), they reported a negative association between farmers' awareness of climate change and the source of credit. Small, self-sufficient farmers with insufficient wealth are susceptible to climate change than other big farmers with more properties and resources.

Our research results showed that farmers' availability to extension services is positively linked with their climate change awareness. Our findings are consistent with (BRYAN et al., 2009; DERESSA et al., 2011), indicating a positive relationship between each other extensive contribution and climate change awareness. Similarly, prior research on the relationship between extension services access and level of awareness about climate changed (LUSENO et al., 2003; DERESSA et al., 2011; MUDOMBI et al., 2014), also showed that access to extension services encouraged farmers in their farms to adopt new technologies, which may lead to agricultural productivity. Also, the close correlation between the extension services availability and the dependent variable suggested that farmers who contact extension officers may increase their climate change concepts.

There is a significant connection between information access and the farmers' awareness, which indicated that farmers with sufficient info material gain access to or understanding about climate change, being highly conscious of climatic events. Farmers stated that the government was the central information source in the study area. Our results are consistent with DERESSA et al. (2009) who defined an as beneficial linkage between awareness of climate change and information sources access. For example, as farmers obtain information sources, their capability to adapt climate change increases. We have found that farmers who rely solely on government agencies as their primary information source/knowledge about climate change were better aware of climate change.

\section{CONCLUSION AND RECOMMENDATIONS}

The awareness level of farmers is influenced by many factors, including socioeconomic and demographic factors. In this study, 500 farmer's households in Punjab Province, Pakistan were selected through a random sampling method. Our results showed that the majority of farmers in the study area are aware of climate change. Results indicated that farmers perceived that their agriculture productivity previously affected with climate change. Socioeconomic factors like farmers' age, education level, agricultural experience, landholding, and access to extension \& information services have positive significant impact on awareness level of climate change. Our findings showed that the farmers are already involved in vigorous adaptation strategies. Moreover, studying and analyzing the adaptation and perceptions of farmers' behavior also helps provided a complete significant awareness of climate change in determining agricultural programs' importance. Our findings could also benefit government organizers and agricultural expansion employees to increase their climate change awareness services in vulnerable areas that are least protected. Although, this study was limited to Punjab, Pakistan, the research outcomes can be applied in other districts where climate change adaptations and mitigations are still unproductive. This study recommends a useful path for legislators and scholars to develop the essential strategies and provide various facilities to farmers that could handle different climatic hazards. However, we need to take the necessary actions to raise awareness of climate change. The focus on these research efforts can in grain crop diversification and high-yield varieties. To strengthen such actions, it is necessary to vigorously implement policies and adopt fully supported methods to improve the ability of farmers to participate in adaptation plans. It is also suggested that farmers' climate change awareness must be encouraged by information technology and mass communication. However, future research is needed to realize how the IT sector can help farm households raise awareness of climate change in other developing countries.

DECLARATION OF CONFLICT OF
INTEREST

The authors declare no conflict of interest.

\section{BIOETHICS AND BIOSSECURITY COMMITTEE APPROVAL}

We authors of the article entitled "An Evaluation of Farmers' Perception, Awareness, and adaptation towards climate change: A Study from Punjab Province Pakistan " declared, for all due purposes, the project that gave rise to the present data of the same has not been submitted for evaluation to the Ethics 
Committee of the University /Research Institute "College of Urban and Environmental Sciences, Northwest University Xi'an, China", but we are aware of the contents of Resolution No. 466, of December 12, 2012 of the Brazilian National Health Council "http://conselho.saude.gov.br/resolucoes/2012/Reso466.pdf" if it involves human.

Thus, the authors assume full responsibility for the presented data and are available for possible questions, should they be required by the competent authorities.

\section{ACKNOWLEDGEMENTS}

We thank our teammates for their valuable suggestions. Especially, we will be grateful to the editor and anonymous reviewers for providing numerous comments and suggestions, who helped to improve this manuscript. The first author would like to thank his parents who support him in this work.

\section{AUTHORS' CONTRIBUTIONS}

MSM and GL conceived and designed the study. ARK and BNS performed statistical analyses, WUHT, ATK and MAR prepared the draft of the manuscript. All authors critically revised the manuscript and approved of the final version.

\section{REFERENCES}

ACQUAH, H. D. Public awareness and quality of knowledge regarding climate change in Ghana: a logistic regression approach. Journal of Sustainable Development in Africa, v.13, n.3, p.146157. 2011. Available from: <https://jsd-africa.com/>. Accessed: Sep. 10, 2020.

ADGER, W. N.; P. M. KELLY. Social vulnerability to climate change and the architecture of entitlements. Mitigation and Adaptation Strategies for Global Change, v.4, n.3-4, p.253-266. 1999. Available from: <https://sci-hub.se/https://link.springer.com/ article/10.1023/A:1009601904210>. Accessed: Sep. 15, 2020. doi: 10.1023/A:1009601904210.

AHMAD, M., et al. Climate change, agriculture and food security in Pakistan: adaptation options and strategies. Pakistan Institute of Development Economics, Islamabad.(Climate Change Brief). 2013. Available from: <https://www.pide.org.pk/>. Accessed: Sep. 15,2020 .

AJUANG, C. O., et al. Determinants of climate change awareness level in upper Nyakach Division, Kisumu County, Kenya. SpringerPlus, v.5, n.1, p.1015. 2016. Available from: <https:// springerplus.springeropen.com/articles/10.1186/s40064-0162699-y>. Accessed: Sep. 15, 2020. doi: 10.1186/s40064-0162699-y.

AYDOGDU, M. H.; K. YENIGÜN. Farmers' risk perception towards climate change: a case of the GAP-Şanlıurfa Region, Turkey. Sustainability, v.8, n.8, p.806. 2016. Available from: $<$ https://www.mdpi.com/2071-1050/8/8/806>. Accessed: Sep. 10 2020. doi: $10.3390 / \mathrm{su} 8080806$

BAYARD, B., et al. The economics of adoption and management of alley cropping in Haiti. Journal of environmental management, v.84, n.1, p.62-70. 2007. Available from: <https:// www.sciencedirect.com/science/article/pii/S0301479706001319>. Accessed: Oct. 18, 2020. doi: 10.1016/j.jenvman.2006.05.001.
BENISTON, M. Climatic change in mountain regions: a review of possible impacts. In: (Ed.). Climate variability and change in high elevation regions: Past, present $\&$ future: Springer, 2003. Climatic change in mountain regions, p.5-31. Available from: $<$ https://link.springer.com/article/10.1023/A:1024458411589>. Accessed: Aug. 20, 2020. doi: 10.1023/A:1024458411589.

BENISTON, M.; W. HAEBERLI. Sensitivity of mountain regions to climatic change. Université de Fribourg2000. 2000. Available from: < https://www.geo.de/>. Accessed: Sep. 15, 2020.

BRYAN, E., et al. Adaptation to climate change in Ethiopia and South Africa: options and constraints. Environmental science \& policy, v.12, n.4, p.413-426. 2009. Available from: $<$ https://www. sciencedirect.com/science/article/abs/pii/S1462901108001263>. Accessed: Aug. 12, 2020. doi: 10.1016/j.envsci.2008.11.002.

DERESSA, T. T., et al. Perception of and adaptation to climate change by farmers in the Nile basin of Ethiopia. The Journal of Agricultural Science, v.149, n.1, p.23-31. 2011. Available from: <https:/www. cambridge.org/core/journals/journal-of-agricultural-science/article/ perception-of-and-adaptation-to-climate-change-by-farmers-inthe-nile-basin-of-ethiopia/98FC44BF50B3E78DC8205A464097C DB8\#>. Accessed: Sep. 15, 2020. doi: 10.1017/S0021859610000687.

DERESSA, T. T., et al. Determinants of farmers' choice of adaptation methods to climate change in the Nile Basin of Ethiopia. Global Environmental Change, v.19, n.2, p.248-255. 2009. Available from: <https://www.sciencedirect.com/science/ article/abs/pii/S0959378009000156>. Accessed: Jul. 22, 2020. doi: 10.1016/j.gloenvcha.2009.01.002.

DI FALCO, S., et al. Does adaptation to climate change provide food security? A micro-perspective from Ethiopia. American Journal of Agricultural Economics, v.93, n.3, p.829-846. 2011. Available from: <https://onlinelibrary.wiley.com/doi/abs/10.1093/ ajae/aar006>. Accessed: Oct. 13, 2020. doi: 10.1093/ajae/aar006.

ESHAM, M.; C. GARFORTH. Agricultural adaptation to climate change: Insights from a farming community in Sri Lanka. Mitigation and Adaptation Strategies for Global Change, v.18, n.5, p.535-549. 2013. Available from: <https://link.springer.com/ article/10.1007/s11027-012-9374-6>. Accessed: Sep. 15, 2020. doi: $10.1007 / \mathrm{s} 11027-012-9374-6$.

FAHAD, S.; J. WANG. Farmers' risk perception, vulnerability, and adaptation to climate change in rural Pakistan. Land use policy, v.79, p.301-309. 2018. Available from: <https://www.sciencedirect. com/science/article/abs/pii/S0264837718306227>. Accessed: Oct. 10, 2020. doi: 10.1016/j.landusepol.2018.08.018.

FAHAD, S., et al. Empirical analysis of factors influencing farmers crop insurance decisions in Pakistan: Evidence from Khyber Pakhtunkhwa province. Land use policy, v.75, p.459-467. 2018. Available from: <https://www.sciencedirect.com/science/article/ abs/pii/S026483771830351X>. Accessed: Accessed: Sep. 15, 2020. doi: 10.1016/j.landusepol.2018.04.016.

FIELD, C. B., et al. Managing the risks of extreme events and disasters to advance climate change adaptation: special report of the intergovernmental panel on climate change: Cambridge University Press. 2012. Available from: $<$ https://www.cambridge. org/core/books/managing-the-risks-of-extreme-events-anddisasters-to-advance-climate-change-adaptation/0D6C7E5AA D12D00CB305C9933422989C > . Accessed: Sep. 15, 2020. doi: $10.1017 /$ CBO9781139177245. 
GOP. Economic Survey of Pakistan. Economic Affairs Division. Ministry of Finance. Islamabad, Pakistan. 2013. Available from: $<$ https://www.finance.gov.pk/survey_1819.html $>$. Accessed: Oct. $15,2020$.

HASAN, Z.; S. AKHTER. Determinants of public awareness and attitudes on climate change in urban Bangladesh: Dhaka as a case. European Journal of Social Sciences, v.21, n.1, p.154-162. 2011. Available from: <https://www.europeanjournalofsocialsciences. com/index.html $>$. Accessed: Oct. 15, 2020.

HASSAN, R. M.; C. NHEMACHENA. Determinants of African farmers' strategies for adapting to climate change: Multinomial choice analysis. African Journal of Agricultural and Resource Economics, v.2, n.311-2016-5521, p.83-104. 2008. Available from: <https://ageconsearch.umn.edu/record/56969>. Accessed: Sep. 12,2020

HUONG, N. T. L., et al. Farmers' perception, awareness and adaptation to climate change: evidence from northwest Vietnam. International Journal of Climate Change Strategies and Management. 2017. Available from: $<$ https://www.emerald.com/ insight/content/doi/10.1108/IJCCSM-02-2017-0032/full/html>. Accessed: Aug. 13, 2020. doi: 10.1108/IJCCSM-02-2017-0032.

HUONG, N. T. L., et al. Economic impact of climate change on agriculture using Ricardian approach: A case of northwest Vietnam. Journal of the Saudi Society of Agricultural Sciences, v.18, n.4, p.449-457. 2019a. Available from: <https://www.sciencedirect. com/science/article/pii/S1658077X17304290>. Accessed: Jul. 10, 2020. doi: 10.1016/j.jssas.2018.02.006.

HUONG, N. T. L., et al. Assessing household livelihood vulnerability to climate change: The case of Northwest Vietnam. Human and Ecological Risk Assessment: An International Journal, v.25, n.5, p.1157-1175. 2019b. Available from: $<$ https://www.tandfonline.com/doi/abs/10.1080/10807039.2018 .1460801 ?journalCode=bher20 $>$. Accessed: Sep. 10, 2020. doi: 10.1080/10807039.2018.1460801.

HUSSAIN, A.; G. B. THAPA. Smallholders' access to agricultural credit in Pakistan. Food Security, v.4, n.1, p.73-85. 2012. Available from: $<$ https://link.springer.com/article/10.1007/s12571-012-0167-2>. Accessed: Jul. 15, 2020. doi: 10.1007/s12571-012-0167-2.

HUSSAIN, S. S.; M. MUDASSER. Prospects for wheat production under changing climate in mountain areas of Pakistan-An econometric analysis. Agricultural Systems, v.94, n.2, p.494-501. 2007. Available from: < https://www.sciencedirect.com/science/ article/abs/pii/S0308521X06002071>. Accessed: Sep. 12, 2020. doi: 10.1016/j.agsy.2006.12.001

IDRISA, Y. L., et al. Analysis of awareness and adaptation to climate change among farmers in the Sahel Savannah agro-ecological zone of Borno State, Nigeria. British Journal of Environment \& Climate Change, n.2, p.216-226. 2012. Available from: <www. sciencedomain.org>. Accessed: Aug. 13, 2020.

IPCC. Synthesis Report. Contribution of Working Groups I, II and III to the Fourth Assessment Report of the Intergovernmental Panel on Climate Change. IPCC. Geneva, Switzerland. 2007. Available from: <https://www.ipcc.ch/report/ ar4/syr/>. Accessed: Sep. 15, 2020.

JAIN, M., et al. Understanding the causes and consequences of differential decision-making in adaptation research: adapting to a delayed monsoon onset in Gujarat, India. Global Environmental Change, v.31, p.98-109. 2015. Available from: <https://www. sciencedirect.com/science/article/abs/pii/S0959378014002179>. Accessed: Aug. 15, 2020. doi: 10.1016/j.gloenvcha.2014.12.008.

KABUBO-MARIARA, J. Climate change adaptation and livestock activity choices in Kenya: An economic analysis: Wiley Online Library. 2008, p.131-141. Available from: <https:// onlinelibrary.wiley.com/doi/full/10.1111/j.1477-8947.2008.00178. $\mathrm{x}>$. Accessed: Aug. 15, 2020. doi: 10.1111/j.14778947.2008.00178.x.

KOHLER, T.; D. MASELLI. Mountains and climate change. From understanding to action: Geographica Bernensia. 2009. Available from: <http://www.cde.unibe.ch/userfiles/Fullversion low_Mountains_and\%20_Climate_Change.pdf $>$. Accessed: Aug. 15, 2020 . doi: 10.7892 /boris.36553.

KRUPNIK, T. J., et al. Untangling crop management and environmental influences on wheat yield variability in Bangladesh: an application of non-parametric approaches. Agricultural Systems, v.139, p.166-179. 2015. Available from: <https://www. sciencedirect.com/science/article/abs/pii/S0308521X15000748>. Accessed: Jul. 22, 2020. doi: 10.1016/j.agsy.2015.05.007.

KURUKULASURIYA, P.; R. MENDELSOHN. A Ricardian analysis of the impact of climate change on African cropland: The World Bank. 2007. Available from: <https://elibrary. worldbank.org/doi/abs/10.1596/1813-9450-4305>. Accessed: Oct. 15, 2020. doi: 10.1596/1813-9450-4305.

LUSENO, W. K., et al. Assessing the value of climate forecast information for pastoralists: Evidence from Southern Ethiopia and Northern Kenya. World development, v.31, n.9, p.1477-1494. 2003. Available from: $<$ https://www.sciencedirect.com/science/ article/abs/pii/S0305750X0300113X>. Accessed: Sep. 22, 2020. doi: 10.1016/S0305-750X(03)00113-X.

MADDISON, D. The perception of and adaptation to climate change in Africa: The World Bank. 2007 Available from: $<$ https:// elibrary.worldbank.org/doi/abs/10.1596/1813-9450-4308>. Accessed: Aug. 15, 2020. doi: 10.1596/1813-9450-4308.

MANDLENI, B.; F. D. K. ANIM. Climate change awareness and decision on adaptation measures by livestock farmers in South Africa. Journal of Agricultural Science, v.3, n.3, p.258. 2011. Available from: $\quad<$ https://www.ccsenet.org/journal/index.php/jas/article/ view/12140>. Accessed: Aug. 12, 2020. doi: 10.5539/jas.v3n3p258.

MTAMBANENGWE, F., et al. Climate change and variability: smallholder farming communities in Zimbabwe portray a varied understanding. African Crop Science Journal, v.20, p.227-241. 2012. Available from: <https://www.ajol.info/index.php/acsj/ article/view/81755>. Accessed: Oct. 12, 2020.

MUDOMBI, S., et al. Socio-economic determinants of climate change awareness among communal farmers in two districts of Zimbabwe. Africa Insight, v.44, n.2, p.1-15. 2014. Available from: $\quad<$ https://journals.co.za/content/afrins/44/2/EJC164288>. Accessed: Aug. 15, 2020.

NDMA. Pakistan Floods 2014: Recovery Needs Assessment and Action Framework 2014-16. National Disaster Management Authority. Islamabad 2014. Available from: <http://web.ndma.gov. pk/publications/Recovery_Needs_Assessment.pdf $>$. Accessed: Aug. 15, 2020. 
ODUNIYI, O. S. Climate change awareness: a case study of small scale maize farmers in Mpumalanga province, South Africa. (PhD Thesis). University of South Africa, 2013. Available from: $\quad<$ http://uir.unisa.ac.za/bitstream/handle/10500/13677/ dissertation_oduniyi_os.pdf?seque>. Accessed: Aug. 12, 2020.

OKONYA, J. S., et al. Farmers' perception of and coping strategies to climate change: Evidence from six agro-ecological zones of Uganda. Journal of Agricultural Science, v.5, n.8, p.252. 2013. Available from: $\quad<$ https://www.ccsenet.org/journal/index.php/jas/article/ view/26639>. Accessed: Jul. 22, 2020. doi: 10.5539/jas.v5n8p252.

OLAJIDE, F. O., et al. Knowledge about the causes, consequences and control of climate change among undergraduates of ObafemiAwolowo University, Ile Ife. In: (Ed.). Environmental Research and Challenge of Sustainable Development: OAU Press, 2011. Available from: <https://oauife.edu.ng/research>. Accessed: Aug. 22, 2020.

PACHAURI, S.; D. SPRENG. Measuring and monitoring energy poverty. Energy policy, v.39, n.12, p.7497-7504. 2011. Available from: $\quad<$ https://www.sciencedirect.com/science/article/abs/pii/ S0301421511005313>. Accessed: Aug. 15, 2020. doi: 10.1016/j. enpol.2011.07.008.

PULHIN, J., et al. Vulnerability of communities to climate variability and extremes: the Pantabangan-Carranglan watershed in the Philippines. AIACCWorking Paper, v.44. 2006. Available from: <www.aiaccproject.org>. Accessed: Jul. 22, 2020.

SOFOLUWE, N. A., et al. Farmers perception and adaptation to climate change in Osun State, Nigeria. African Journal of Agricultural Research, v.6, n.20, p.4789-4794. 2011. Available from: < http://www.academicjournals.org/AJAR>. Accessed: Sep. 15, 2020. doi: 10.5897/AJAR10.935.
STEFFEN, W., et al. Planetary boundaries: Guiding human development on a changing planet. Science, v.347, n.6223. 2015. Available from: <https://science.sciencemag.org/ content/347/6223/1259855.long >. Accessed: Oct. 15, 2020. doi: $10.1126 /$ science. 125985 .

STERRETT, C. Review of climate change adaptation practices in South Asia. Oxfam Policy and Practice: Climate Change and Resilience, v.7, n.4, p.65-164. 2011. Available from: <https:// www.oxfam.org/en/research/review-climate-change-adaptationpractices-south-asia>. Accessed: Jul. 22, 2020.

THORNTON, P. K.; M. HERRERO. Climate change adaptation in mixed crop-livestock systems in developing countries. Global Food Security, v.3, n.2, p.99-107. 2014. Available from: $\quad<$ https://www.sciencedirect.com/science/article/abs/pii/ S2211912414000108>. Accessed: Sep. 12, 2020. doi: 10.1016/j. gfs.2014.02.002.

VELANDIA, M., et al. Factors affecting farmers' utilization of agricultural risk management tools: the case of crop insurance, forward contracting, and spreading sales. Journal of agricultural and applied economics, v.41, n.1, p.107-123. 2009. Available from: $\quad<$ https://www.cambridge.org/core/journals/journal-ofagricultural-and-applied-economics/article/abs/factors-affectingfarmers-utilization-of-agricultural-risk-management-tools-thecase-of-crop-insurance-forward-contracting-and-spreadingsales/7D94838364CD023E382A4EE437CD46A3>. Accessed: Sep. 12, 2020. doi. 10.1017/S1074070800002583.

ZHANG, M., et al. Extreme drought changes in Southwest China from 1960 to 2009. Journal of Geographical Sciences, v.23, n.1, p.3-16. 2013. Available from: <https://link.springer.com/ article/10.1007/s11442-013-0989-7>. Accessed: Aug. 12, 2020. doi: 10.1007/s11442-013-0989-7. 